\title{
An examination of the trash recovered at Armstrong Lunar Park
}

\section{On a roll. By Wendy Nikel}

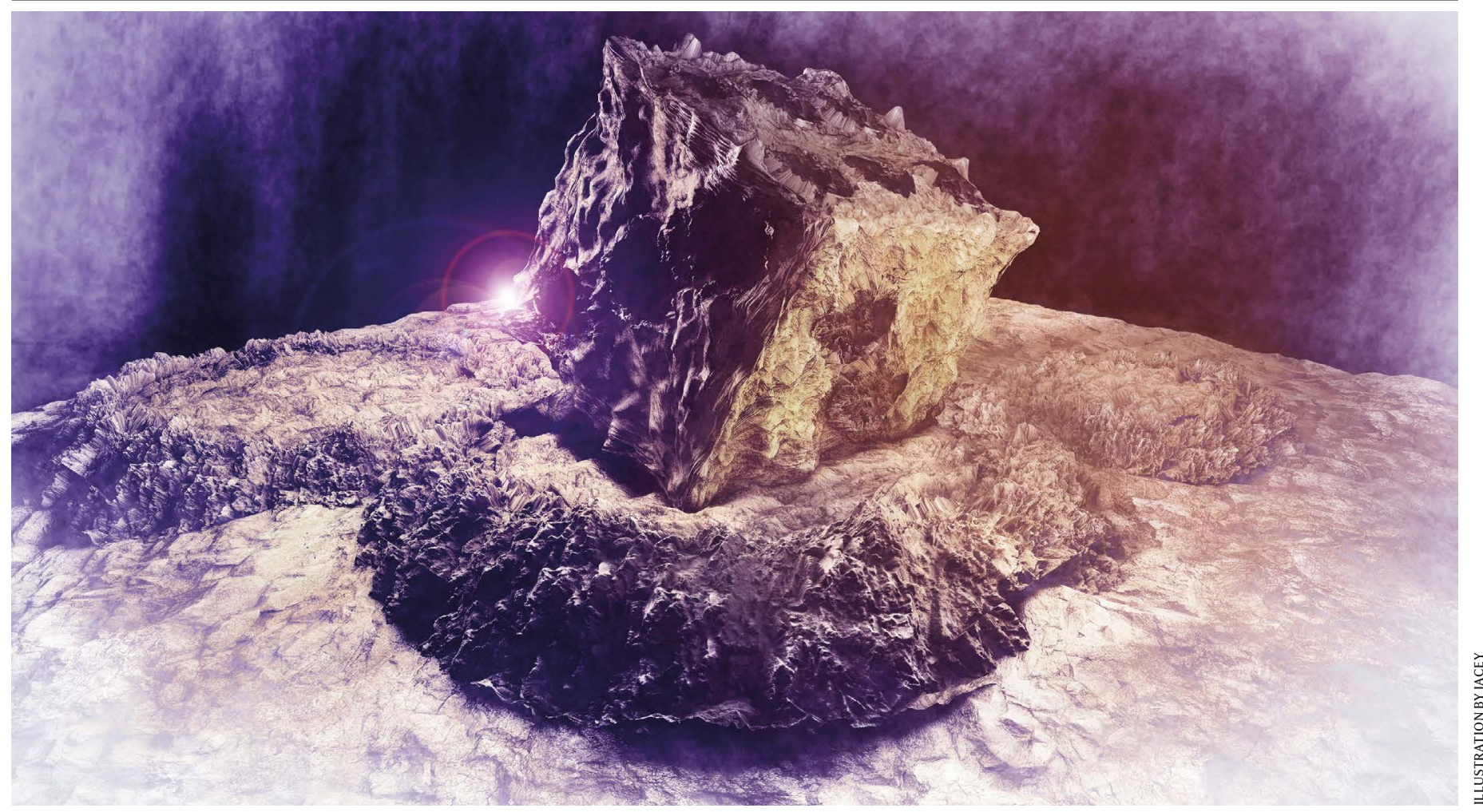

ive depleted barrels of rocket fuel. One defective heat shield. Twelve metallized polypropylene bags designed to hold a single ounce of Cheetos each, flying in the face of the Lunar Park's list of prohibited items.

I shove the trash into Rover's bin. The shutdown doesn't stop billionaires from flying here in their personal rockets and trashing the place, but it does stop me from getting paid to pick up after them. Yet I'm here anyway, my skin sticking to my spacesuit's plasticky insides, out of some warped sense of loyalty. If not to the park, then to the Moon herself.

Also, because the die told me to.

When I asked whether I should 'borrow' the department's shuttle to fly up here and check on things, it rolled a 12. Can't argue with that, even if it is costing me an arm and a leg in fuel and supplies.

For the past year - since my judgement lapse led to a billion-dollar error and three-week hospital stay - I've determined to rely solely on fate. So far, it hasn't steered me wrong.

I press Rover's button and his titanium treads beeline to the landfill on the far side. Out of sight, out of mind, I think bitterly.

I'm about to head back to the ranger station for a well-deserved sponge bath and protein bar snack (odds, the chocolate one; evens, peanut butter) when something on the edge of a distant crater catches my eye. More junk, no doubt.

I check my oxygen levels. What could it be this time? A brokenjet-propelled photography drone? Abandoned solar panels? It's amazing the stuff people leave here, discarded without a second thought to its environmental impact. My glove-encased fingers worm their way into my pocket and pull out my oversized lucky D12. Odds, I check it out; evens, I head back. The die kicks up a feathering of dust, landing with three dots upward. I scoop it up, tuck it away, and bound off.

It's difficult to determine scale on the Moon. There's nothing but craters to compare things to, and those can vary from microscopic to 290 klicks across. I can tell, though, as I approach, that this object is bigger than a drone or panel.

It's the size of a ship. A ship that landed roughly enough to bend its landing gear's legs and spew aluminium and metal in a debris field around it. It's 14 klicks short of the landing zone, probably because the pilot had no idea what they were doing. Either that, or they were trying to hide something.

The hatch is open, but when I look inside, no one's there.

A bungee cord's anchored beside the ladder, with the end hanging into the crater. Sure enough, when I peer down, there's some idiot clinging to it. 


\section{Futures}

I click onto the emergency channel. "You okay?"

The spacesuit moves, and a curse transmits through the radio. “I thought there weren't any rangers out here."

"I could leave." I should leave. Trying to aid an imperilled visitor is what got me into such hot water a year ago. Turned out, that visitor wasn't actually in peril; he'd gone outside the park boundaries to hide his illicit excavation and didn't take too kindly to my interference.

“No!” The intruder yells. “Please! Help me! I ... I've been trying to get back up, but ..."

My hand goes to my pocket. My gut says this guy's not going to knock me out and leave me for dead, but l've been wrong before.

Better let the fates decide.

Odds, I help; evens, I leave this rule-breaking spacetrash to sort out this mess himself. I toss the die and it rolls to the crater's edge, but as I reach for it, I catch sight of the blue glow of Earth beyond.

I hesitate.
That miraculous orb is what l'd fixed my pain-deluded mind on as I'd crawled back towards the park that day, dragging my busted leg behind me. It'd given me hope, knowing that if I just kept crawling towards it, I'd find help.

But today, there's no one out here on this rock but me. If this trespasser were to break a bone or puncture his suit trying to get out of that crater, it'd be too late before anyone else could reach him. Today, I am his hope.

The die sits silently - fate, within my reach. I grab the cable instead. My heart pounds, recalling the last time l'd relied on my own instinct, that moment I realized I'd misjudged the situation. But some decisions - even if they turn out badly - are too important to be trusted to fate.

“Hang on. I'll pull you up."

He pants as I haul him the last few metres to the surface. When he's caught his breath, he turns to face me, and I tense, waiting for him to turn on me and prove my fears right. The attack I'm waiting for doesn't come.

"You're not going to turn me in, are you?" he asks.

"For your illegal landing, illegal bungee jumping, or damage to park property?"

The white die reflects in his helmet. Odds, Iturn him in; evens ...

"No." I shake my head and press the button to summon Rover to my location. "I won't turn you in. But I will require you to do some community service while you're here. You can start by cleaning up this mess."

"Absolutely! This will be the cleanest crater you've ever - Whoa. What's this thing?" He holds up the die.

Odds, I keep it; evens ...

“Toss it," I say, turning to face Earth. "It's nothing but a bit of space junk."

Wendy Nikel is a speculative-fiction author with a degree in elementary education, a fondness for road trips and a terrible habit of forgetting where she's left her cup of tea. For 